ЦЕЛОВАЛЬНИКОВА Ирина Ивановна - кандидат исторических наук, доцент кафедры истории Ульяновского государственного педагогического университета им. И.Н. Ульянова (432071, Россия, 2. Ульяновск, пл. Ленина, 4/5, celo-iri@yandex.ru)

\title{
СИСТЕМА ПРОДОВОЛЬСТВЕННОГО СНАБЖЕНИЯ НАСЕЛЕНИЯ И ОРГАНИЗАЦИЯ ПОСТАВОК ХЛЕБА ДЛЯ АРМИИ В РОССИИ В ГОДЫ ПЕРВОЙ МИРОВОЙ ВОЙНЫ (на примере Симбирской губернии)
}

\begin{abstract}
Аннотация. В статье рассматривается деятельность Министерства земледелия и Особого совещания по продовольственному делу по организации снабжения населения и поставок хлеба для армии в годы Первой мировой войны. Значительное внимание уделяется изучению формирования системы закупок для армии на местах и деятельности уполномоченных на основе земских органов самоуправления. Автор анализирует причины неудач в поставках хлеба, приходит к выводу об отсутствии единства и четкой согласованности в работе системы военных поставок.
\end{abstract}

Ключевые слова: поставки продовольствия для армии, Особое совещание по продовольственному делу, Первая мировая война, сельское хозяйство, Симбирская губерния

B годы войны от успешности продовольственного снабжения армии и тыла во многом зависит успех всей военной кампании. В годы Первой мировой войны российское правительство создало систему государственных органов, обладавших чрезвычайными полномочиями в деле организации снабжения армии и населения тыловых районов продовольствием. В 1914 г. снабжение осуществлялось Главным интендантским управлением (ГИНТУ) при содействии Главного управления землеустройства и земледелия (ГУЗиЗ), переименованного в конце 1915 г. в Министерство земледелия. ГИНТУ определяло размеры нарядов на закупку продовольствия и фуража, передавало их ГУЗиЗу, которое выполняло наряды через своих уполномоченных. Привлечение ГУЗиЗа было обусловлено желанием использовать механизм взаимодействия между государственными органами и земствами в деле продовольственного снабжения армии. На местах создается система ГУЗиЗа по закупкам продовольствия, которая включала уполномоченных, в качестве которых обычно выступали председатели губернских земских управ, а также губернские и уездные продовольственные комитеты, создававшиеся на основе тех же земских управ. В связи с необходимостью консолидации системы продовольственного снабжения армии, а также разграничения сфер ответственности между Военным ведомством и ГУЗиЗом 19 мая 1915 г. создается Главный продовольственный комитет во главе с министром торговли и промышленности. 17 августа 1915 г. Продовольственный комитет был преобразован в Особое совещание для обсуждения и объединения мероприятий по продовольственному делу, которое возглавил глава ГУЗиЗа А.В. Кривошеин. Однако и после этого сохранялась некоторая разобщенность и несогласованность в системе заготовок продовольствия для армии. Если закупка продовольствия для армии и продовольственное снабжение населения сосредоточивались в руках уполномоченных Особого совещания, то право реквизиции продуктов - у уполномоченных Министерства земледелия, а именно у отдела заготовок [Оськин 2017: 194-196, 202]. При этом назначение реквизиций вхо- 
дило также и в компетенцию Особого совещания, согласно п. 9 Положения о его деятельности.

Особое совещание носило межведомственный характер и было призвано объединять правительственные мероприятия по заготовке продовольствия и фуража для армии, а также по организации продовольственного снабжения населения в целом. В состав Особого совещания входили представители всех ведомств, могуших быть задействованными в данном деле: Государственного совета, Государственной думы, МВД, Военного министерства, министерств финансов, путей сообщения, торговли и промышленности, Государственного контроля, ГУЗиЗа, Всероссийских земского и городского союзов. Особое совещание наделялось полномочиями высшего органа власти - ни одно правительственное учреждение не могло давать ему предписаний и требовать от него отчета. Только военный министр, являвшийся председателем Особого совещания по обороне, мог приостанавливать действие его постановлений ${ }^{1}$. Предоставление таких исключительных прав говорило о той важности, которую придавало правительство организации продовольственного снабжения армии, а также о неудовлетворительном состоянии в данной сфере.

Председатель Особого совещания мог требовать содействия от всех правительственных и общественных учреждений, имел право вмешиваться в работу частных предприятий, запрашивать информацию о хранившихся у них запасах продовольствия и фуража, обеспечивая тем самым преимущественное исполнение государственных заказов. По требованию Особого совещания частные владельцы должны были предоставлять складские помещения (за исключением железнодорожных), а в местностях, объявленных на военном положении, они могли быть секвестированы и переданы под управление назначенных лиц.

В своей деятельности Особое совещание существенно ограничивало работу местных органов власти и самоуправления, отменяя постановления губернских властей и общественных учреждений, касавшиеся продовольственного обеспечения населения, установления правил торговли и предельных цен на продовольствие, обладало правом назначать реквизицию скота и продовольствия, определять условия их проведения. Военные закупки осуществлялись на средства, выделенные Советом министров или в экстренных случаях министром финансов 2 .

На местах в своей деятельности Особое совещание опиралось на земские органы самоуправления; закупки осуществлялись уполномоченными особых совещаний. Одной из первоочередных задач для них стала организация местных совещаний на различных уровнях: губернском, областном и городском. В Симбирской губернии уполномоченным Особого совещания был назначен председатель губернской земской управы Н.Ф. Беляков, который одновременно совмещал должность уполномоченного ГУЗиЗа. Таким образом удалось избежать проблемы координации в деятельности уполномоченных, проводить согласованные мероприятия по закупке продовольствия для армии и продовольственного снабжения населения в губернии. Местные совещания занимались выяснением потребности населения в продовольствии, определяли размеры продовольственных запасов в торговых компаниях и складских помещениях. В сферу их деятельности входило также регулирование цен на местном рынке продовольствия, в т.ч. через закупку и создание на местах продовольственных запасов за счет средств Государственного казначейства. В про-

1 Государственный архив Ульяновской области (ГАУО). Ф. 46. Оп. 2. Д. 778. Л. 1.

2 Там же. Л. 2-4. 
грамме губернского совещания при симбирском уполномоченном председателя Особого совещания 18 декабря 1915 г. предлагалось разделить губернию на районы по железнодорожным станциям, к которым они тяготели, произвести теоретический расчет годовых норм потребления населением продовольственных товаров первой необходимости для каждого района, установить размеры имевшихся там торговых запасов. Для нормализации снабжения населения предметами первой необходимости было решено ввести ежедневную регистрацию прибытия грузов по всем железнодорожным станциям на территории Симбирской губернии. Регистрационные карточки по наиболее крупным станциям (Симбирская, Часовня, две Сызранские) должны были доставляться уполномоченному ежедневно, по остальным станциям - еженедельно. К первоочередным задачам относились не только обеспечение внеочередной отправки грузов по железной дороге, но и установление предельных цен на ряд продуктов для сельских местностей, прежде всего на сахар. В связи с усложнением работы местные уполномоченные приступили к организации местных совещаний по продовольственному вопросу ${ }^{1}$.

Основной задачей, которую были призваны решать уполномоченные, являлась закупка хлеба для армии. В этих целях Правилами о порядке покупки для надобности армии хлеба из будущего урожая от 17 июня 1915 г. разрешалась выдача задатков под закупаемый хлеб отдельным землевладельцам, сельским обществам и уездным земским управам. Количество приобретаемого хлеба из будущего урожая определялось по размерам земельного владения, посевных площадей и средних урожаев. Относительно сельских обществ решение принималось уездной земской управой. Размер выдаваемых задатков зависел от количества закупаемого хлеба и достигал $25 \%$, в некоторых случаях - $40 \%$ общей суммы. В договоре оговаривались время, место поставки, а также качество поставляемого продукта, которое должно было соответствовать условиям мирного времени. В случае отказа от поставки продавец обязан был вернуть казне задаток в двойном размере, в случае частичного невыполнения договора - уплатить $20 \%$ стоимости недоставленного продукта. Цена на хлеб определялась в соответствии с ценой, установленной для данной местности совещанием, или на основании средней продажной цены на местной бирже, могла утверждаться уполномоченным, который исходил из средних цен за последнее пятилетие с повышением их не более чем на $12 \%$. Сельская община должна была круговой порукой гарантировать выполнение договора или возврат задатка в двойном размере ${ }^{2}$. Система предполагала осуществление закупок у непосредственных производителей, исключая посредников. На практике же у частных посредников уполномоченные приобретали примерно 1/2 всего хлеба, т.е. данное условие в значительной степени не выполнялось [Рынков 2016: 71].

Уже в 1915 г. в связи с необходимостью снабжения армии ГУЗиЗ вводит твердые цены на продовольствие. Согласно постановлению от 5 октября 1915 г., устанавливались твердые цены на овес. В случае отказа продавцов предоставлять овес по твердым ценам в отношении них разрешалось применять реквизицию с понижением цены на $15 \%$. Земским и городским органам самоуправления предлагалось обратиться к населению с разъяснением необходимости отказа от кормления домашней скотины овсом с целью отправки его в армию, рекомендовать использовать в качестве кормов ячмень и жмых, сообщать имеющиеся способы кормления данными продуктами. В случае реквизиции хозяевам оставляли лишь семенной овес. В Самарской, Саратовской, Симбирской,

\footnotetext{
1 Там же. Л. 13.

2 Там же. Л. 14.
} 
Казанской губерниях до урожая 1916 г. на овес устанавливалась твердая цена в 1 руб. 10 коп. ${ }^{1}$ Установление твердых цен должно было не только обеспечить успешность военных поставок, но и нормализовать продовольственное снабжение городского населения, ограничить рост цен на рынке продовольствия. Симбирское губернское земское собрание 4 августа 1916 г. пришло к заключению, что успешность введения твердых цен возможна лишь при условии их распространения по всей территории России не только на правительственные заготовки для армии, но и на все частные сделки [Кобзева 2014: 173]. В 1915 г. недостаточным был и запас ячменя. Закупить удалось лишь около 10 тыс. пудов $^{2}$. Дефицит продовольствия и рост инфляции привели к постепенному установлению твердых цен на все значимые товары: к 9 сентября 1916 г. установились твердые цены на все хлеба. Цена на рожь в Симбирской губернии была установлена в 1,52 руб., на овес - 1,58 руб., гречневую крупу - 3,4 руб., горох - до 2,4 руб. ${ }^{3}$

В целях обеспечения продовольственных поставок для армии и снабжения населения также вводились ограничения в губерниях на вывоз некоторых видов продовольствия. Разрешение на вывоз предоставляли, помимо Особых совещаний, также командующие военными округами. Так, в телеграмме командующего войсками Казанского военного округа от 25 апреля 1915 г. симбирскому губернатору сообщалось о разрешении на свободный вывоз хлебов в зерне и муке за исключением овса, ячменя, гречневой крупы, а также продовольствия и фуража, закупленных и реквизированных для нужд военного ведомства. Также сохранялся ранее введенный запрет на вывоз партий муки ржаной, размольной, обойной и обдирной, ржи и пшеницы, которые были осмотрены уполномоченными по закупке хлеба для армии и представлены губернатору для реквизиции ${ }^{4}$.

Предпринятые организационные меры, а также введение твердых цен, реквизиции и ограничение свободного вывоза хлеба дали некоторые результаты. Уже с 1915 г. местным уполномоченным Особого совещания и ГУЗиЗа с опорой на земские органы самоуправления удалось организовать регулярные поставки продовольствия для армии. Уполномоченный Н.Ф. Беляков докладывал в Петроград о заготовке хлеба в Симбирской губернии с начала операции по 4 мая 1915 г.: овса - 1366830 пудов, ржи - 288 572,5 пуда, муки - 1981521 пуд, пшена - 460700 пудов, макарон - 18500 пудов 5 .

Одной из существенных проблем в деле заготовок хлеба для армии стала задержка перевода авансов на покупку хлеба из Петрограда. Деньги поступали, но уполномоченные сетовали на дефицит средств и просили ускорить их перевод ввиду срочности платежей. С каждым годом данная проблема только усиливалась. В телеграмме губернского уполномоченного Н.Ф. Белякова в Петроград от 2 мая 1915 г. сообщалось о получении в качестве аванса для закупки хлеба для армии 3900 тыс. руб., из земских сумм было заимствовано 21 520,58 руб. Таким образом, всего на закупку хлеба было выделено 4221 520,58 руб., израсходовано на эти цели - 4142 088,22 руб., остаток составил 79 432,36 руб. ${ }^{6}$ Необходимость осуществления платежей по заключенным ранее договорам на поставку зерна для армии побуждала уполномоченного просить Петроград ускорить перевод

1 Там же. Л. 10.

2 Там же. Л. 108.

3 Твердые цены. Постановление Министерства Земледелия. 9 сентября 1916 г. 1916. Вестник мелкого кредита. № 37. С. 1482-1487.

4 ГАУО. Ф. 46. ОП. 2. Д. 780. Л. 4.

5 Там же. Л. 128.

6 Там же. Л. 48. 
авансов. Уже 4 мая 1915 г. Н.Ф. Беляков сообщал: «...на текущем счете денег не осталось. Предстоят очень крупные срочные платежи, контрагенты сильно жалуются на неисправность в платежах. Все дело сильно тормозится за отсутствием денег» 1 .

Однако еще более серьезной проблемой в деле заготовок продовольствия для армии стала нехватка мест для хранения уже закупленного хлеба. Так, уполномоченный в Сызранском уезде Симбирской губернии Монстров доносил 30 апреля 1915 г. в Симбирск о невозможности принять муку и расплатиться с поставщиками ввиду отсутствия свободных складских помещений, многие из которых были заняты частными грузами. Аналогичные донесения были доставлены губернскому уполномоченному Н.Ф. Белякову из Алатыря 29 апреля 1915 г., в которых местный уполномоченный просил немедленно освободить помещение в разъезде Басово между городами Алатырь и Ардатов в Симбирской губернии: «Поступающую пшеницу негде складывать. Несем большие убытки» 2 . Оценивая масштабы проблемы нехватки помещений для хранения заготовленного для армии хлеба, Симбирская губернская земская управа сообщала в Петроград: «Задерживается вся операция системной заготовки» ${ }^{3}$.

Неудовлетворительными условиями хранения во многом объяснялась плохая сохранность закупленного для армии хлеба. Согласно актам приемных комиссий ГУЗиЗа о качестве хлеба, поставленного для армии от Симбирской губернии в апреле 1915 г., в 2 из 10 вскрытых мешков с мукой купца Кузмичева, хранившихся в пакгаузе на станции Чуфарово, были обнаружены комки «слегшейся и позеленевшей муки»; овес, поставленный крестьянином Котыревым, хранившийся на станции Майна, имел затхлый запах и общую засоренность в 43\%; овес крестьянина Карпычева содержал примесь «полугнилой пшеницы»; во всех случаях влажность поставляемого для армии зерна превышала установленные нормы ${ }^{4}$. Главноуполномоченный по закупке хлеба для армии обращал внимание Н.Ф. Белякова на отсутствие в местных актах о приемке заключения комиссии о качестве принимаемого зерна и даже высказал предположение, что продукты эти были забракованы, а акты высланы только для сведения.

Частыми были также случаи несоответствия веса сданного нахранение зерна, закупленного для армии, тому, что был указан в актах приемной комиссии. Недостача постоянно обнаруживалась при перевозке зерна на мельницы, при загрузке его на баржи. Так, Буинская уездная земская управа сообщала в 1916 г. уполномоченному Н.Ф. Белякову, что в приемных книгах и накладных значилось гораздо больше хлебных грузов, чем реально доставлялось по железной дороге на станцию Ибреси, куда свозился весь хлеб для армии в данном уезде 5 . Недостача на каждый вагон составляла 2-4 мешка муки из 223 отправленных по накладным 6 . Во всех случаях пломбы на вагонах были целыми. Причинами такого состояния дел могли быть: нарушение правил приемки грузов в отсутствие жандарма, что создавало возможность для хищений, усушка зерна от долгого хранения, потери от грызунов и от пересыпки, вследствие порчи мешков. Так, агроном 2-го участка Буинской уездной земской управы сообщал 2 ноября 1915 г. о приемке на станции Ибреси, согласно накладным,

\footnotetext{
1 Там же. Л. 120.

2 Там же. Л. 16, 45.

3 Там же. Л. 111.

4 Там же. Л. 23.

5 Там же. Л. 18.

6 Там же. Л. 21-32.
} 
21942 пудов овса для армии; недостача по указанным выше причинам составила 332 пуда ${ }^{1}$.

Загруженность железных дорог, скопление продовольственных грузов на станциях, необходимость военных поставок, сокращение посевных площадей привели к значительному ухудшению продовольственного снабжения городов. Критическое положение сложилось весной 1915 г. в городе Алатыре. Закупленная местными торговцами ржаная мука не могла быть доставлена в город по причине «несвободного железнодорожного сообщения». На предложение городской управы о продаже населению хотя бы половины закупленной для нужд армии ржаной муки, хранившейся на городских складах, был получен отказ $^{2}$. В связи со сложившейся ситуацией в губернии губернатор даже ходатайствовал в 1915 г. перед командующим Казанским округом о «прекращении в пределах Симбирской губернии заготовления хлебов для армии» ${ }^{3}$. Прошение не было удовлетворено, т.к. данный вопрос не входил в компетенцию командующего.

Обеспечение поставок хлеба для армии в данных условиях оказалось под угрозой срыва, особенно серьезной была ситуация с закупкой овса. Уполномоченный по Симбирской губернии, председатель губернской земской управы 1 мая 1915 г. докладывал главноуполномоченному, что, «хотя покупка... продолжается и ныне, но уже в количествах исчерпывающих по-видимому свободную наличность овса на местных рынках и является опасение за приостановку операции покупки овса, что в интересах армии совершенно недопустимо» ${ }^{2}$. Н.Ф. Беляков предложил для решения проблемы снабжения армии фуражом воспользоваться общественными хлебными запасами. Данные запасы служили обеспечением сельским обывателям на случай неурожая и голода, хранились в запасных магазинах, по закону принадлежали сельским обществам и могли расходоваться только на их продовольственные нужды, а также для обеспечения семенным материалом. Тем не менее уполномоченный считал возможным в сложившейся ситуации приобрести этот овес для армии за наличный расчет или простым заимствованием с обязательством немедленного возврата в том же объеме после завершения закупочной операции. В сельских общественных магазинах Симбирской губернии в это время хранилось до 200 тыс. пудов овса, этого должно было хватить для выполнения норм поставок 5 .

Таким образом, созданная государством в годы войны система закупок продовольствия для армии и снабжения населения характеризовалась отсутствием единства и четкой согласованности в работе, осуществлялась одновременно Особым совещанием, отделом закупок Министерства земледелия и командующими военными округами, что негативно сказывалось на осуществлении военных поставок. Ситуацию с обеспечением армии еще больше осложняло нерациональное расходование продовольственных запасов в связи с ошибочным расчетом на скорое окончание войны [Валяев, Ганжов, Мошкин 2017: 144]. Продовольственная политика российского правительства в годы Первой мировой войны, проявившаяся в деятельности Особого совещания по продовольственному делу и Министерства земледелия, значительно ограничивала действие рыночных отношений в стране, являлась одним из механизмов усиления государственного регулирования экономики. Следующим шагом к уси-

${ }^{1}$ ГАУО. Ф. 46. ОП. 2. Д. 771. Л. 19, 28.

2 Там же. Л. 24-25.

3 ГАУО. Ф. 46. ОП. 2. Д. 780. Л. 4.

4 Там же. Л. 40.

5 Там же. Л. 40(об)- 41. 
лению регулирования продовольственного снабжения стало введение 25 марта 1917 г. закона о монополии на хлеб, который фактически не был реализован, но в условиях ослабления центральной власти в России стал дестабилизирующим фактором, разрушавшим рынок [Оськин 2015: 166].

\section{Список литературы}

Валяев Я.В., Ганжов Е.А., Мошкин А.Н. 2017. Система продовольственного снабжения российской армии в годы Первой мировой войны (август 1914 г. февраль 1917 г.). - Научные ведомости Белгородского государственного университета. Сер. История. Политология. № 22(271). С. 139-146.

Кобзева Т.А. 2014. Земства Среднего Поволжья в годы Первой мировой войны (на материалах Симбирской губернии). - Власть. № 2. С. 170-173.

Оськин М.В. 2015. Продовольственный вопрос в России в 1917 году: слабое место новой власти. - Научные ведомости Белгородского государственного университета. Сер. История. Политология. № 7(204). С. 164-171.

Оськин М.В. 2017. Продовольственная политика Министерства земледелия в период Первой мировой войны (июль 1914 - февраль 1917 г.). - Вестник Российского университета дружбы народов. Сер. История России. Т. 16. № 2. C. 190-209.

Рынков В.М. 2016. Аграрная экономика под прессом государственного администрирования: из опыта времен Первой мировой войны. - Экономический журнал. № 3(43). С. 68-97.

\section{RUSSIA'S SYSTEM OF THE POPULATION FOOD SUPPLY AND THE ORGANIZATION OF THE ARMY BREAD SUPPLIES DURING THE FIRST WORLD WAR (the example of the Simbirsk Province)}

\footnotetext{
Abstract. The author examines the activities of the Ministry of Agriculture and the Special Meeting on Food Business to organize the population supply and the army bread supply during the World War I. Considerable attention is paid to the study as of the local procurement system as to the activities of authorities in the Zemstvo self-government bodies. The author analyzes the failures reasons in the bread supply and concludes that there is no unity and clear consistency in the military food supply system.

Keywords: food supplies for army, Special Meeting on Food Business, World War I, agriculture, Simbirsk Province
} 